\title{
LIN52 wt Allele
}

National Cancer Institute

\section{Source}

National Cancer Institute. LIN52 wt Allele. NCI Thesaurus. Code C162419.

Human LIN52 wild-type allele is located in the vicinity of $14 \mathrm{q} 24.3$ and is approximately $116 \mathrm{~kb}$ in length. This allele, which encodes protein lin-52 homolog, plays a role in the regulation of cell cycle gene expression. 